\title{
Genomic insight of two indigenous probiotics Lactobacillus plantarum Dad-13 and Lactobacillus plantarum Mut-7 from different origins of Indonesian fermented foods
}

\author{
DIAN ANGGRAINI SUROTO ${ }^{1,2,3, \boldsymbol{v}}$, PRATAMA NUR HASAN ${ }^{2,3}$, ENDANG SUTRISWATI RAHAYU $^{1,2,3}$ \\ 'Department of Food Science and Technology, Faculty of Agricultural Technology, Universitas Gadjah Mada. Jl. Flora 1, Sleman 55281, Yogyakarta, \\ Indonesia \\ ${ }^{2}$ Center for Food and Nutrition Studies, Universitas Gadjah Mada. Jl. Teknika Utara, Sleman 55281, Yogyakarta, Indonesia \\ ${ }^{3}$ University Center of Excellence for Research and Application on Integrated Probiotic Industry, Univeristas Gadjah Mada. Jl. Teknika Utara, Sleman \\ 55281, Yogyakarta, Indonesia
}

Manuscript received: 9 September. Revision accepted: 25 November 2021.

\begin{abstract}
Suroto DA, Hasan PN, Rahayu ES. 2021. Genomic insight of two indigenous probiotics Lactobacillus plantarum Dad-13 and Lactobacillus plantarum Mut-7 from different origins of Indonesian fermented foods. Biodiversitas 22: 5491-5500. Lactobacillus plantarum Dad-13 and Lactobacillus plantarum Mut-7 are probiotics isolated from traditional fermented foods. In the present study two strains of L. plantarum were sequenced using Illumina NovaSeq PE150 platform and in silico analysis was performed using RAST webserver to unravel the functional metabolic between two strains. The $L$. plantarum Dad-13 and Mut-7 genome sizes were 3.25 and $3.98 \mathrm{Mb}$ with GC content of them being almost similar i.e. 44.4 and $44.3 \%$, respectively. Two lactobacilli also had some differences in their metabolic genes, particularly in carbohydrate subsystem. L. plantarum Mut-7 had genes related to the metabolisms of plant cell wall components such as dextrin, arabinose, xylose indicated the adaptation to their environmental origins (fermented dried cassava), while those genes were not observed in L. plantarum Dad-13 which was isolated from fermented buffalo's milk (dadih). Further analysis using BAGEL4 webserver exhibited their different potential to synthesize bacteriocins, L. plantarum Dad-13 was predicted to produce more types of bacteriocins than $L$. plantarum Mut-7. This investigation revealed that L. plantarum Dad-13 and L. plantarum Mut-7 have a great potential related with their properties as probiotics.
\end{abstract}

Keywords: Bacteriocins, fermented foods, genomic analysis, Lactobacillus plantarum, probiotics

\section{INTRODUCTION}

Lactic acid bacteria (LAB) are well known to inhabit diverse environments, such as in carbohydrate-rich food of plants (Sakandar et al. 2019; Ashaolu and Reale 2020) and animal origin (Albayrak and Duran 2021; Gupta et al. 2021), mucosa and intestinal of human or animal (Medjaoui et al. 2016; Fečkaninová et al. 2019; Li et al. 2020), terrestrial and aquatic environment (Sica et al. 2010; Fhoula et al. 2013; Prasirtsak et al. 2013).

LAB have a substantial role in fermented foods, such that they enhance flavor, increase nutritional value and even play a role as food preservatives (Nuraida 2015; Behera et al. 2020). LAB are known to have probiotic properties due to their health beneficial effects (Linares et al. 2017; Ayivi et al. 2020). Probiotics can maintain the condition of the digestive tract by inhibiting the growth of pathogenic bacteria and increasing favorable bacteria (Sarkono et al. 2010; Bermundez-britho et al. 2012; Trush et al. 2020). The functional properties of probiotic are strain dependent, and each strain has unique characteristics and functional properties (Shiroda and Manning 2020; Sophatha et al. 2020).

Lactobacillus plantarum plays an important role in well-known fermented foods of animal and vegetable origin including kimchi, sauerkraut, cheese, kefir, sourdough, vegetable pickles (Nuraida 2015; Tamang et al. 2016) and recognized as Generally Recognized as Safe (GRAS) by Food and Drug Administration (Behera et al. 2018). L. plantarum showed survival ability against gastric acid and bile salt and can colonize in the human intestinal tract (Le and Yang 2018; Zhang et al. 2020) make them a suitable candidate for probiotics development. In addition, $L$. plantarum is attracting medical science due to its cholesterol-lowering properties, reducing blood level, anticancer properties, kidney protection properties, and immunomodulatory properties (Arasu et al. 2016).

LAB as probiotics are also strongly affected by their ability to produce bacteriocins as antibacterial substances that can inhibit the growth of pathogenic bacteria (Bermudez-britho et al. 2012; Ramu et al. 2015). L. plantarum produces a group of bacteriocins known as plantaricins that show antibacterial properties against a handful of pathogenic bacteria (Todorov et al. 2016; Butorac et al. 2020; Ahaddin et al. 2021), and show potential for food preservatives (Kareem and Razavi 2019).

Indonesian indigenous fermented foods have a long history of benefiting from lactic acid bacteria. L. plantarum has been isolated from several kinds of Indonesian indigenous fermented food, such as tempoyak, mandai, gatot, growol, dadih, bekasam etc (Nuraida 2015). Several strains of $L$. plantarum have been isolated from plant and 
animal origin of fermented foods. L. plantarum Dad-13 isolated from dadih (fermented buffalo's milk) and $L$. plantarum Mut-7 isolated from gatot (fermented dried cassava) (Rahayu 2003). These isolates showed health benefit properties and potential candidates for local probiotics. L. plantarum Dad-13 could increase the population of Lactobacilli and inhibit the growth of Enterobacteriaceae (Rahayu et al. 2016); L. plantarum Mut-7 could increase the population of Lactobacillus in fecal and could survive in intestine (Fitrianingthias et al. 2018). The safety assessment of two L. plantarum also has been studied (Rahayu et al. 2019; Ikhsani et al. 2020). The whole study indicated that those strains are promising local probiotics for Indonesian population.

The aim of the present study was to perform genomic analysis of two L. plantarum strains to explore their strainspecific characteristic and their capability to produce secondary metabolites, especially bacteriocins.

\section{MATERIAL AND METHODS}

\section{Bacterial strains and culture}

L. plantarum Dad-13 and Mut-7 were obtained from FNCC (Food and Nutrition Culture Collection), Center of Food and Nutrition Studies Universitas Gadjah Mada, Yogyakarta, Indonesia. Isolates were inoculated in de Man Rogosa and Sharpe (MRS) broth and incubated at $37^{\circ} \mathrm{C}$ for 36-48 hours.

\section{Bacterial genomic extraction}

Genomic DNA was extracted by the SDS method (Lim et al. 2016a). The harvested DNA was detected by agarose gel electrophoresis and quantified by Qubit® 2.0 Fluorometer (Thermo Scientific).

\section{Library construction and sequencing}

A total amount of $1 \mu \mathrm{g}$ DNA per sample was used as input material for DNA sample preparation. Sequencing libraries were generated using NEBNext ${ }^{\circledR}$ Ultra $^{\text {TM }}$ DNA Library Prep Kit for Illumina (NEB, USA) following the manufacturer's recommendations and index codes were added to attribute sequences to each sample. Briefly, DNA sample was fragmented by sonication to a size of $350 \mathrm{bp}$, then DNA fragments were end-polished, Atailed, and ligated with the full-length adaptor for Illumina sequencing for further PCR amplification. At last, PCR products were purified (AMPure XP system) and libraries were analysed for size distribution by Agilent 2100 Bioanalyzer and quantified using real-time PCR. The genome sequencing was performed using Illumina NovaSeq PE150 platform.

\section{Genome assembly}

De novo assembly of raw reads data was performed by SOAP denovo software, followed by SPAdes software (version SPAdes-3.12.0-Linux) in a Linux environment (Bankevich et al. 2012), different K-mers (99 and 127) were selected for assembly. According to the project type, assembly result was obtained with the optimal K-mer and the least scaffolds. The results from SPAdes were assembled using AbySS software (Simpson et al. 2009). Kmer 64 was selected for assembly. The assembly results of three softwares were integrated with CISA software (Lin and Liao 2013), and assembly result with the least scaffolds were selected. The SOAPGapcloser software (Luo et al. 2021) was used to fill the gap of preliminary assembly results.

\section{Bioinformatic analysis}

Genome annotation was identified by using the online program Rapid Annotation using Subsystem Technologies (RAST) SEED (http://rast.nmpdr.org/) (Overbeek et al. 2014). Secondary metabolites gene clusters were predicted using AntiSMASH 6 (https://antismash.secondarymetabolites.org/) (Blin et al. 2021). Further annotations of bacteriocin gene clusters were performed using Bagel4 (http://bagel4.molgenrug.nl/index.php) (van Heel et al. 2014).

\section{RESULTS AND DISCUSSION}

\section{Genome features of Lactobacillus plantarum Dad-13 and L. plantarum Mut-7}

The present study revealed that two indigenous strains have different genome sizes. The circular L. plantarum Mut-7 genome was approximately $0.147 \mathrm{Mb}$ larger than $L$. plantarum Dad-13, with GC content being almost similar i.e. 44.4 and $44.3 \%$. Consequently, Mut-7 contained more coding sequences as well as RNA. Gene prediction and annotation showed that L. plantarum Dad-13 and Mut-7 possess 3074 and 3214 coding sequences, respectively (Table 1). The genome size and GC content of Mut-7 and Dad-13 are within the range observed for most $L$. plantarum strains ( $\mathrm{Yu}$ et al. 2017; Kim et al. 2020). The different size and number of genes have also been studied in L. plantarum (Yu et al. 2017; Rodrigo-torres et al. 2019; Kim et al. 2020). L. plantarum Dad-13 and Mut-7 were almost identical in the protein sequence as shown in Figure 1. However, some regions showed low identity, mainly hypothetical proteins and phages.

Table 1. Genome features of Lactobacillus plantarum Dad-13 and L. plantarum Mut-7

\begin{tabular}{lll}
\hline \multicolumn{1}{c}{ Features } & \multicolumn{1}{c}{$\begin{array}{c}\text { L. plantarum } \\
\text { Dad-13 }\end{array}$} & \multicolumn{1}{c}{$\begin{array}{c}\text { L. plantarum } \\
\text { Mut-7 }\end{array}$} \\
\hline Genome size (bp) & $3,250,375$ & $3,398,000$ \\
\%GC content & $44.4 \%$ & $44.3 \%$ \\
RNA & 75 & 87 \\
Coding sequences & 3074 & 3214 \\
N50 (bp) & 332,562 & 163,062 \\
No of contigs & 27 & 36 \\
\hline
\end{tabular}




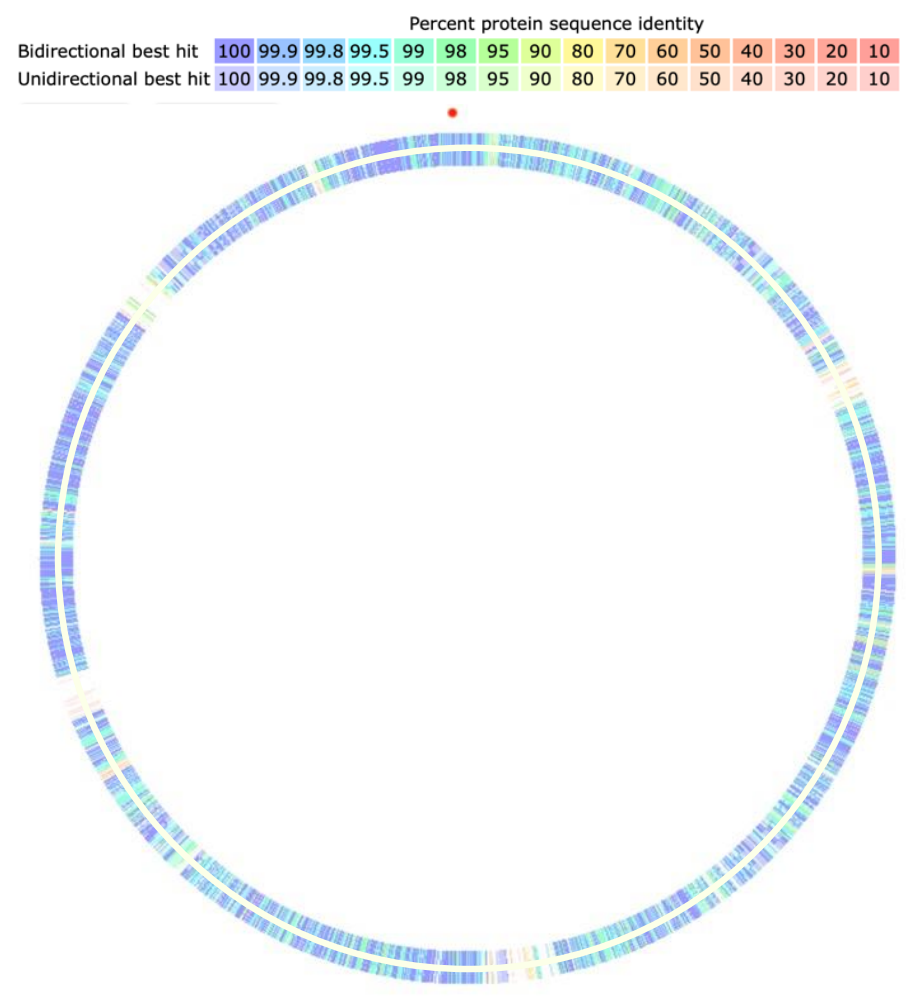

Figure 1. Graphical genomic comparison map of Lactobacillus plantarum strains with Seed Viewer sequenced-based comparison tool in RAST webserver. From outer to inner ring: strain Mut-7, Dad-13. Colors denote amino acid similarity percentage to the reference genome, from purple (100\%) to light red (10\%)

\section{In silico analysis of functional metabolic pathways}

Based on RAST analysis, the coverage subsystems of $L$. plantarum Dad-13 had a total of 1273 features, with 1217 non-hypotethical subsystem and 56 hypotethical subsystem. $L$. plantarum Mut-7 had 1337 features including 1279 nonhypothetical subsystems and 58 hypothetical subsystems. In both strains genes related to carbohydrate subsystem category had high proportion followed by amino acid and derivatives, protein metabolisms, cell wall and capsule, cofactors, vitamins and prosthetic group, and RNA metabolisms (Figure 2). Mut-7 encoded 456 genes on carbohydrate subsystem, while Dad-13 encoded only 416 genes, Mut-7 encoded 231 genes on amino acids and derivatives followed by 223 genes in Dad-13. The number of genes related to capsule and cell wall, DNA metabolism, phage and prophages, and amino acid derivative protein metabolisms in L. plantarum Mut-7 were 147, 98, 28, 231, 188, respectively, which was comparatively larger than Lactobacillus Dad-13. Plasmids, which may transfer their genetic material to other microorganisms, were not detected in both lactobacilli.

The two strains have mostly common functional genes, however there were some differences in both lactobacilli. Especially in carbohydrate subsystem category, followed by cell wall and capsule subsystem, DNA metabolism, phages, prophages, transposable elements, and amino acid and derivatives category (Figure 2). While the numbers of other genes were almost similar, but some genes were present in several copies, or some unique genes were present in only one strain. L. plantarum Mut-7 and $L$. plantarum Dad-13 had 56 and 13 extra unique genes, respectively (Table 2). In L. plantarum Mut-7, 17 of extra unique genes were related to carbohydrate metabolism, especially fructose-1,6-bisphosphatase, PEP Pyruvate carboxyl transferase, maltose-6'-phosphate glucosidase, some gene related to xylose, arabinose utilization subsystem. Indeed, they also shared some genes related to carbohydrate metabolism such as for maltodextrin utilization, but maltose-6'-phosphate glucosidase was absent in Dad-13. Exclusively several genes for xylose and arabinose utilization were only present in Mut-7. The unique genes for monosaccharide utilization seem related to plant-based origin of L. plantarum Mut-7 in which sugars like dextrin, arabinose, and xylose are common in the plant product. This phenomenon was also observed in Lactococcus lactis from plant origin that show the presence of dextrin, arabinose, and xylose while the one from animal origin did not, indicated the adaptation to their growth in plant cell wall substances (Siezen et al. 2008; Xiao et al. 2021).

Lactobacillus plantarum Dad-13 possessed chitinase, a beta glucosidase related to lichenan, a complex glucan consisting of glucosyl connected with $\beta 1,3$ and $\beta 1,4$ bonds, and sucrose 6 phosphate hydrolase. It also occurred in betaglucosidase metabolism and in fructooligoscharides utilization, in which they both shared 39 genes. Even though Mut-7 shared some genes related to chitin and $\mathrm{N}$ acetyl glucosamine, but the chitinases were only present in Dad-13. 
Table 2. Features of unique genes in Lactobacillus plantarum Dad-13 and L. plantarum Mut-7

\begin{tabular}{|c|c|c|c|c|}
\hline \multirow[t]{2}{*}{ Functional subsystems } & \multicolumn{2}{|r|}{ Lactobacillus plantarum Dad-13 } & \multicolumn{2}{|r|}{ Lactobacillus plantarum Mut-7 } \\
\hline & $\begin{array}{l}\text { No of unique } \\
\text { genes }\end{array}$ & Description & $\begin{array}{l}\text { No of unique } \\
\text { genes }\end{array}$ & Description \\
\hline Carbohydrate & 4 & $\begin{array}{l}\text { Chitinase, beta-Glucoside metabolism, } \\
\text { transcriptional antiterminator of lichenan } \\
\text { operon, sucrose-6-phosphate hydrolase }\end{array}$ & 17 & $\begin{array}{l}\text { Fructose-1,6-bisphosphatase pyruvate carboxyl transferase, maltose-6'- } \\
\text { phosphate glucosidase galactitol operon regulator (Transcriptional } \\
\text { antiterminator), arabinose-proton symporter, L-arabinose isomerase, } \\
\text { ribulokinase, transcriptional repressor of arabinoside utilization operon, } \\
\text { L-ribulose-5-phosphate 4-epimerase, alpha-xylosidase, xylose } \\
\text { isomerase, xylose-responsive transcription regulator: ROK family }\end{array}$ \\
\hline Capsule and cell wall & - & - & 7 & $\begin{array}{l}\text { Capsular and extracellular polysaccharide rhamnose containing glycan } \\
\text { synthesis, exopolysaccharide (Glycosyl transferase, group } 2 \text { family } \\
\text { protein), teichoic and lipoteichoic acids biosynthesis CDP } \\
\text { glycerol:poly(glycerophosphate) glycerophosphotransferase } \\
\text { 2.7.8.12) }\end{array}$ \\
\hline DNA metabolism & 3 & $\begin{array}{l}\text { Exonuclease family protein YhaO, bacterial } \\
\text { DNA-cytosine methyltransferase bacterial } \\
\text { MutL-MutS system, MutS domain protein, } \\
\text { family } 4\end{array}$ & 11 & $\begin{array}{l}\text { RecT, DNA topoisomerase III, Type I restriction-modification system, } \\
\text { DNA-methyltransferase subunit M, Type I restriction-modification } \\
\text { system, restriction subunit R, Type I restriction-modification system, } \\
\text { specificity subunit S } \\
\text { CRISPR-associated protein Cas1, CRISPR-associated protein Cas2, } \\
\text { CRISPR-associated protein, Csn1 family }\end{array}$ \\
\hline Amino acids and derivative & - & - & 3 & $\begin{array}{l}\text { D-serine dehydratase transcriptional activator, Intermediate for } \\
\text { synthesis of Tryptophan, PAPA antibiotics, PABA, 3- } \\
\text { hydroxyanthranilate, cysteine biosynthesis, para-aminobenzoate } \\
\text { synthase, amidotransferase component (EC } 2.6 .1 .85 \text { ), }\end{array}$ \\
\hline $\begin{array}{l}\text { Phages, prophages, } \\
\text { transposable element, } \\
\text { plasmid }\end{array}$ & 3 & $\begin{array}{l}\text { Phage capsid scaffolding protein, phage tail } \\
\text { fiber protein, } \quad \text { phage minor capsid protein, }\end{array}$ & 9 & $\begin{array}{l}\text { Phage capsid protein, phage head maturation protease, phage DNA } \\
\text { packaging, phage terminase small subunit, phage tail fiber proteins, } \\
\text { phage tail proteins, phage major tail protein, phage tail assembly }\end{array}$ \\
\hline $\begin{array}{l}\text { Cofactor,vitamins, prosthetic } \\
\text { group }\end{array}$ & - & - & 3 & $\begin{array}{l}\text { NAD and NADP cofactor biosynthesis, riboflavin, FMN, and FAD } \\
\text { metabolism }\end{array}$ \\
\hline Nucleosides and Nucleotides & - & - & 2 & Uridine phosphorylase (EC 2.4.2.3) \\
\hline Phosphorus metabolism & - & - & 1 & High affinity phosphate transporter and control of $\mathrm{PHO}$ \\
\hline Regulation and cell signalling & - & - & 3 & $\begin{array}{l}\text { Autolysis histidine kinase LytS regulation and Cell signaling, autolysis } \\
\text { response regulator LytR, cAMP signaling in bacteria }\end{array}$ \\
\hline Sulfur metabolism & 3 & $\begin{array}{l}\text { Organic sulfur assimilation: alkanesulfonate } \\
\text { assimilation } \\
\text { nitrate/sulfonate/bicarbonate transport systems, } \\
\text { periplasmic components, Alkanesulfonates ABC } \\
\text { transporter ATP-binding protein, }\end{array}$ & - & \\
\hline
\end{tabular}




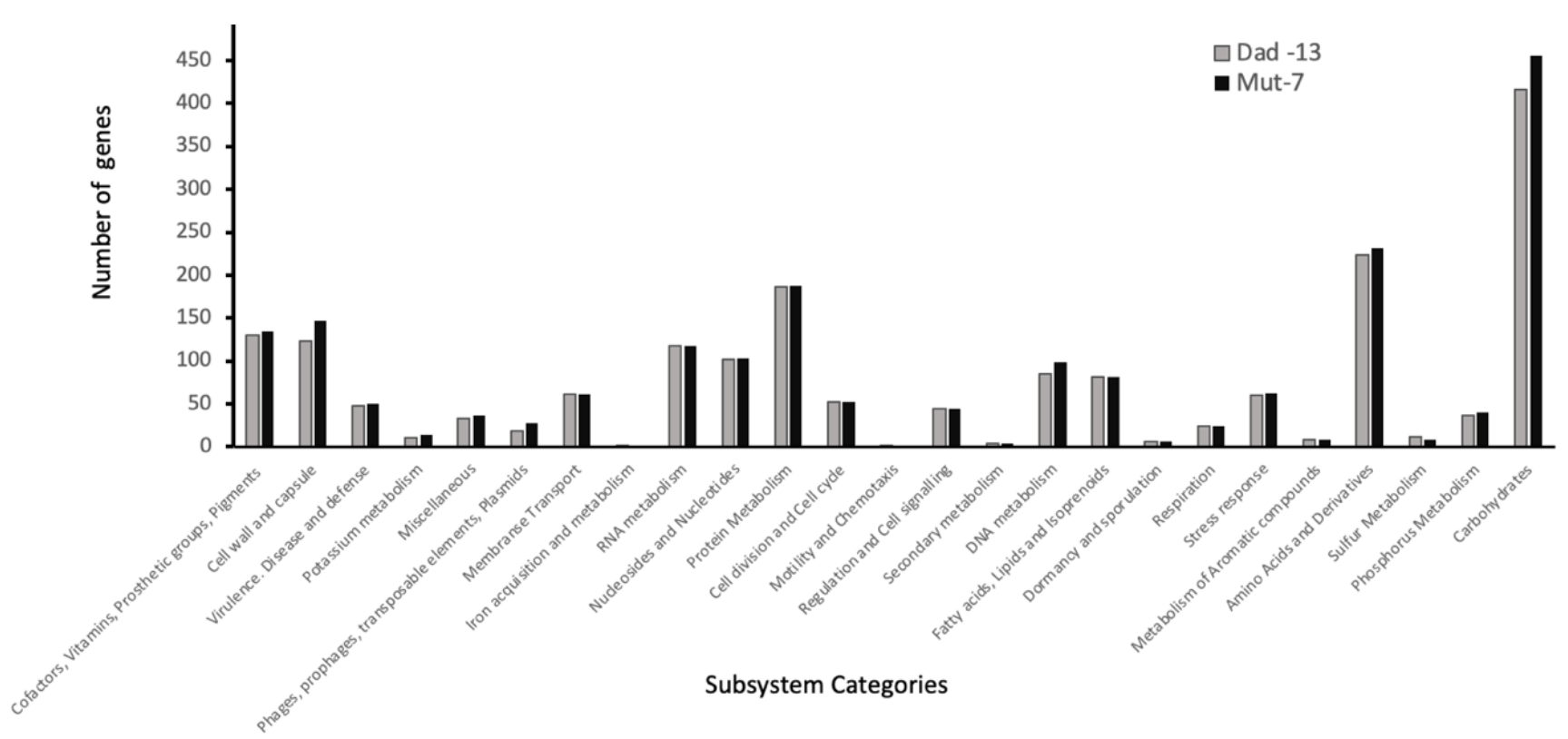

Figure 2. Results of RAST analysis of Lactobacillus plantarum Dad-13 and L. plantarum Mut-7

Lactobacillus plantarum Mut-7 also had a high proportion of unique genes related to cell wall and capsule, DNA metabolism and phages, prophages, transposable elements, plasmids. In the cell wall and capsule category, genes related to capsular and extracellular polysaccharide, especially in rhamnose containing glycan synthesis and exopolysaccharide (EPS) biosynthesis were lacking in Dad13. But, EPS biosynthesis which was encoded by glycosyl transferase group 2 family's gene was present in Mut-7, indicating a potential ability of Mut-7 to produce EPS. EPS are loosely associated with the microbial cell surface and released into the surrounding environment (ChapotChartier and Kulakauskas 2014). The presence of exopolysaccharide- synthesized genes is indicative of its important role in industrial applications, as they give the desired texture to products and some health benefits (Silva et al. 2019).

Genes in rhamnose containing glycan synthesis may play an important role for cell wall synthesis, in which rhamnose is one of the major sugars present in the cell wall of several bacteria Lactococcus, Streptococcus and Enterococcus, and Lactobacillus (Vinogradov 2016; Garcia-Vello et al. 2020).

Lactobacillus plantarum Mut-7 had a unique genes in DNA metabolism which was not present in Dad-13, most genes related to restricted modification system and Clustered Regularly Interspaced Palindromic Repeats (CRISPR) associated proteins. The presence of CRISPRCas proteins in Mut-7 may inhibit the conjugation and bacteriophage infection (Richter et al 2012). They can also prevent the natural transformation of foreign nucleic acids fragments, which can contribute to making this strain genetically more stable (He et al. 2018; Tarrah et al. 2020). These sequences have been shown to be involved in resistance to bacteriophages (Deem et al. 2020). They play a critical role in the adaptation and persistence of a microbial host in a particular ecosystem (Westra et al.2020).

Unlike L. plantarum Mut-7, L. plantarum Dad-13 lacked genes encoding phage capsid proteins, phage head maturation protease, phage DNA packaging, phage packaging machinery, phage terminase small subunit, phage tail fiber proteins, phage major tail protein, phage tail proteins, phage tail assembly. However, Dad-13 possessed genes encoding phage capsid scaffolding protein, phage minor capsid protein, phage tail fiber protein which were absent in Mut-7. In addition, L. plantarum Dad-13 also possessed a unique gene in sulfur metabolism category. Minor number of unique genes in L. plantarum Mut-7 was also observed in amino acid derivatives, cofactors, vitamins, prosthetic group, nucleosides and nucleotides, phosphorus metabolism regulation and cell signalling subsystem category.

\section{In silico analysis of genes related to secondary metabolism}

The results exhibited that both strains had four clusters related to the secondary metabolism, namely terpene, Polyketide Synthase (PKS) type III, Ribosomally Synthesized and Post Translationally Modified Peptide (RiPP), and cyclic lactone autoinducer. Each cluster was predicted to have almost similar size, except RiPP cluster (Table 3). Terpene biosynthetic gene cluster is predicted to involve in phytoene biosynthesis which belongs to carotenoid group. PKS type III showed high homology to chalcone synthetase. encode the same function as hydroxymethylglutaryl-CoA synthase. Chalcone synthase is an enzyme that is responsible for the biosynthesis of flavonoid compounds (Waki et al. 2020), and is widely present in plants, fungi, and bacteria (Austin and Noel 2003; Lim et al. 2016b). 
Table 3. Predicted secondary metabolite gene clusters in Lactobacillus plantarum Dad-13 and L. plantarum Mut-7

\begin{tabular}{lcl}
\hline \multicolumn{1}{c}{ Biosynthetic gene clusters } & \multicolumn{1}{c}{ L. plantarum Dad-13 } & \multicolumn{1}{c}{ L. plantarum Mut-7 } \\
\cline { 2 - 3 } & \multicolumn{1}{c}{ Region/size } & \multicolumn{1}{c}{ Region/size } \\
\hline Terpene & $58,162 \mathrm{nt}-79,043 \mathrm{nt} / 20,881 \mathrm{nt}$ & $434,387 \mathrm{nt}-455,268 \mathrm{nt} / 20,881$ \\
PKS Type III & $309,144 \mathrm{nt}-350,313 \mathrm{nt} / 41,169 \mathrm{nt}$ & $129,364 \mathrm{nt}-170,533 \mathrm{nt} / 41,169 \mathrm{nt}$ \\
Cyclic lactone & $197,434 \mathrm{nt}-218,139 \mathrm{nt} / 20,705 \mathrm{nt}$ & $31,932 \mathrm{nt}-52,687 \mathrm{nt} / 20,755 \mathrm{nt}$ \\
Ribosomally Synthesized and Post Translationally Modified & $441,720 \mathrm{nt}-414,644 \mathrm{nt} / 27,076 \mathrm{nt}$ & $48,957 \mathrm{nt}-60,786 \mathrm{nt} / 11,829 \mathrm{nt}$ \\
Peptide (RiPP) & & \\
\hline
\end{tabular}

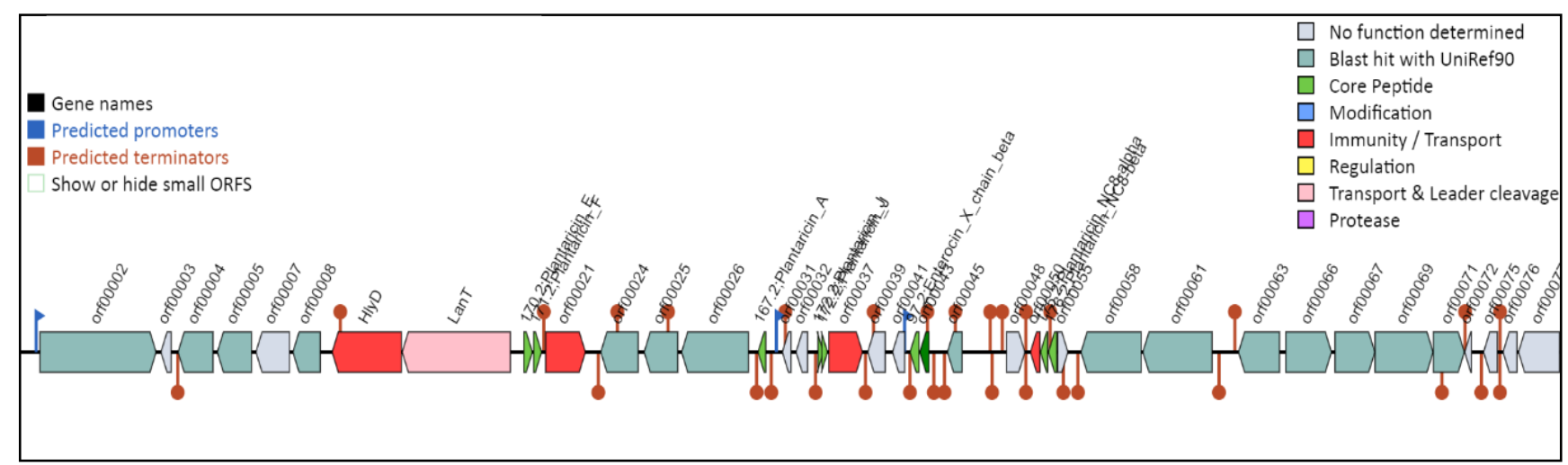

Figure 3. Area of Interest (AOI) Lactobacillus plantarum DAD-13 in scaffold 2. Genes with function are determined from left to right (gene name function). Orf 1-6 hyphotethical protein; orf8, glactoside O-acyctransferase; orf9, drugefflux pump; orf11, S-amino-6(5phopho-D-ribitylamino)uracil phosphatase; orf14,HTH-type transcriptional activator; orf 15, sugar phosphatase; orf 17, branched chain amino acid transportsystem carrier protein; orf $20, \mathrm{Na}(+) / \mathrm{H}(+)$ antiporter; orf 22 , hypothetical protein; comC, plantaricin $\mathrm{NC} 8 \beta$; comC, plantaricin $\mathrm{NC} 8 \alpha$; orf 28 , putative imunity protein; orf31,transposase; orf $33, \mathrm{Na}(+) / \mathrm{H}(+)-\mathrm{K}(+)$ antiporter; orf35, lactococin; comC, enterocin X chain beta; orf37-39, hypothetical protein; orf41, putative bacteriocin immunity protein; plantaricin $J$, Plantaricin $\mathrm{J} ;$ plantaricin $\mathrm{J}$, plantaricin $\mathrm{J}$; orf46-47, hypothetical protein; plantaricin A, plantaricin A; orf52, bacteriocin production related histidine kinase; orf53, response regulator PlnC; orf54, response regulator PlnD; orf59, immunity protein plnI;plantaricin F, planataricin F;plantaricin E, plantaricin E;lantT, bacteriocin $\mathrm{ABC}$ transporter; hylD, accessory factor for ABC-transporter PlnH; orf70, protein Yvdc; orf71, CPBP intramembrane metalloprotease; orf 73, Plns; orf74, PLns; orf 75, hyphotetical protein; orf 77, DNA helicase IV

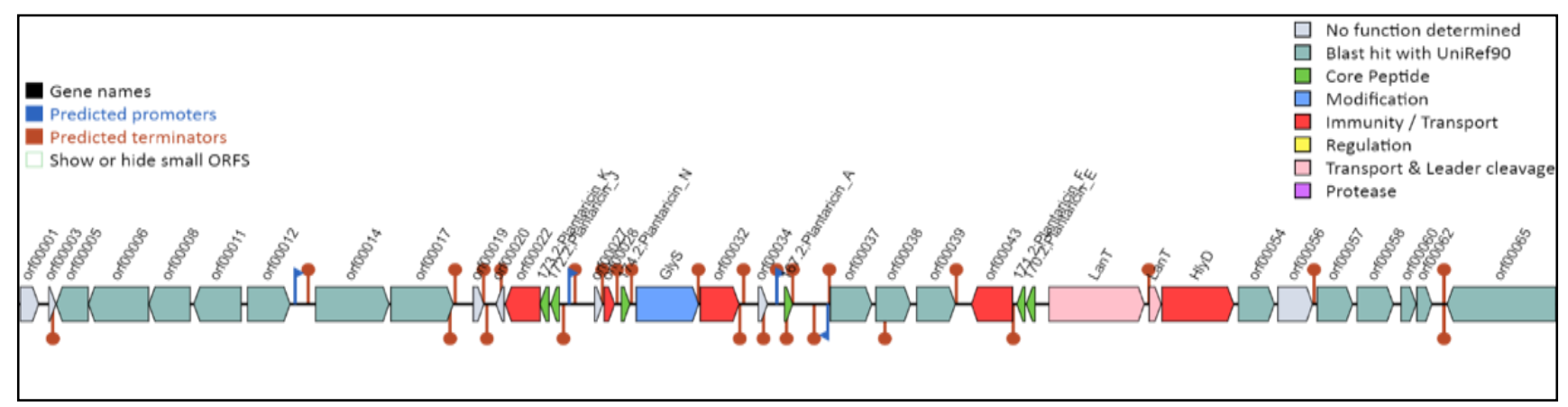

Figure 4. Area of Interest (AOI) Lactobacillus plantarum Mut-7 in scaffold 5. Genes with function are determined from left to right (gene name function). orf1, hyphothetical protein; orf3, hypothetical protein; orf5, galactoside O-acetyltransferase; orf6, methylenomycin A resistance; orf8,5-amino-6 (5-phospho D-ribitylamino) uracil phosphate; orf11,HTH transcriptional activator;orf12 sugarphosphatase; orf14, branched-chain amino acid system;orf17, $\mathrm{Na}(+) / \mathrm{H}(+)$ antiporter; orf19, hyphotethical protein; orf20,plnR; orf 22, putative bacteriocin immunity protein $\mathrm{plnM}$; $\operatorname{comC}$, plantaricin $\mathrm{K}$; plantaricin J, plantaricin J;orf27, hypothetical protein; orf 28, LACPL immunity protein PlnM;plantaricin N, planataricin N;glys $S$, PlnO;orf32, LACPL immunity protein PlnI; orf34, hyphothtetical protein; plantaricin A,plantaricin A; orf37, Bacteriocin related histidine kinase; orf38, response regulator PlnC; orf39, response regulator $\mathrm{PlnD}$; orf43, LACPL immunity protein PLnI; plantaricin F, plantaricin F; plantaricin E, plantaricin E; lanT, bacteriocin ABCtransporter ATP-binding and permease protein; lanT bacteriocin ABC-transporter ATP-binding and permease protein; $H y l D$, Accesory factor for ABC-transporter PlnH; orf54, PlnS; orf56, CPBP family inter membran metalloprotein; orf57, PLnS; orf59, PlnS; orf60:toxin HigB; orf62, plnY; orf65, DNA Helicase IV 
Since Ribosomally Synthesized and Post Translationally Modified Peptide (RiPP) cluster is closely associated with bacteriocins (Mathur et al. 2021). Scaffold 2 of $L$. plantarum Dad-13 and scaffold 5 of L. plantarum Mut-7 which habour RiPP cluster were genome mined using BAGEL4 to know whether by both strains may produce bacteriocins. Lactobacillus, known to produce bacteriocins (Gaspar et al. 2018; Wang et al. 2018; Mira-Villalobos et al. 2020) and other secondary metabolites such as L13 (3phenyl-1, 2, 4-benzotriazine), 3-phenyllactic acid (Arasu et al. 2013; Sentürk et al. 2020). L. plantarum is well known to produce plantaricins, a bacteriocin showing various bactericidal and bacteriostatic activities (Zhu et al. 2014; Wen et al. 2016; Zhao et al. 2016; Wang et al. 2018). Plantaricins together with Pediocins belong to a class II bacteriocins, with small molecular weight of less than 10 $\mathrm{kDa}$, heat-stable, and non-lantibiotic peptides (Barbosa et al. 2021).

It was observed that each cluster can potentially produce several bacteriocins types. The size of bacteriocins gene clusters in Dad-13 and Mut-7 were 30.591 nt and $29.498 \mathrm{nt}$, respectively as predicted by BAGEL4. $L$. plantarum Dad-13 predicted to produce eight types of bacterioncins, namely plantaricins A, E, F, J, NC8 alpha, NC8 beta, lactococin, and enterocin (Figure 3, Table 4), whereas Mut-7 was predicted to produce six types of bacteriocins : plantaricin A, E, F, J, K, and N (Figure 4, Table 5). Each of bacteriocin cluster was equipped with HylD and Lant $\mathrm{T}$ genes which were involved in transport and leader peptide cleavage. In Dad-13, their position was in the upstream region of plantaricin encoding genes, whereas in Mut 7 it was in the downstream region of the bacteriocin gene clusters. LanT gene homologues encoded the bacteriocin $\mathrm{ABC}$ transporter, the ATP binding protein, and the permease protein PlnG.

Various types of plantaricins produced by L. plantarum have antibacterial properties and their mechanism for bacterial growth inhibition varies considerably (Kareem and Razavi 2019). However, at present the prospects of plantaricins are numerous such as, biopreservation agents of raw food, antibacterial packaging agent, anti-cancer, antioxidants, and anti cholesterol agent (Syaputri and Iwahashi 2020). Dad-13 was predicted to produce not only plantaricin bacteriocin but also lactococin and enterocin. Mut-7 was predicted to produce only plantaricin type bacteriocin, particularly plantaricin $\mathrm{K} / \mathrm{N}$, in addition to $\mathrm{A}$, $\mathrm{E}, \mathrm{F}, \mathrm{J}$ but not plantaricin $\mathrm{NC}$, lactococin, and enterocin. Plantaricin, E/F and $\mathrm{J} / \mathrm{K}$ showed antibacterial against Staphylococcus epidermidis by destruction of cell membrane and also show synergistic effect with several antibiotics (Selegård et al. 2019). Plantaricin NC8 $\alpha / \beta$ was found active against Staphylococcus spp. and possibly to be developed as an adjuvant in combination therapy to potentiate the effects of antibiotics and reduce their overall (Bengtsson 2020). The plantaricin A showed a narrow spectrum and weak bacteriocins, acting as inducer for production of plantaricin E/F and J/K (Kareem and Ravazi 2019).

The difference of bacteriocins or plantaricins produced by Dad-13 and Mut-7 may affect their antimicrobial properties. L. plantarum Dad-13 was able to inhibit the growth of Escherichia coli, Shigella dysenteriae, and Salmonella typhi, while L. plantarum Mut-7 showed similar activity but not inhibited S. typhi (Rahayu et al. 2015).

Table 4. BAGEL4 webserver's prediction of plantaricins and their amino acid sequences produced Lactobacillus plantarum Dad-13

\begin{tabular}{llc}
\hline Type of bacteriocins & \multicolumn{1}{c}{ Amino acid sequences } & $\begin{array}{c}\text { Match } \\
\text { score }\end{array}$ \\
\hline Plantaricin E & MLQFEKLQYSRLPQKKLAKISGGFNRGGYNFGKSVRHVVDAIGSVAGIRGILKSIR & $100 \%$ \\
Plantaricin F & MKKFLVLRDRELNAISGGVFHAYSARGVRNNYKSAVGPADWVISAVRGFIHG & $100 \%$ \\
Plantaricin A & VIIMKIQIKSMKQLSNKEMQKIVGGKSSAYSLQMGATAIKQVKKLFKKWGW & $97.92 \%$ \\
Plantaricin J & LEGSWKNFWSSFKFYAGEAGRVVRMSLNTCLNRSHAL & $66.67 \%$ \\
Plantaricin J & MDKTLKNLDTVDAFASISNNKLNGVVGRLLEKFLV & $74.04 \%$ \\
Lactococin & VIKMKNINNFQALQKNELSKVKGGSNNKFWTWAGYTYENWRISSRRAFNLRQRKNTMTHH & $75.86 \%$ \\
Enterococin X chain & MRKSISNFKALNEKELGAVNGGIWQWIVGGLGFLAGDAWSHSDQISSGIKKRKKKGYG & $53.91 \%$ \\
Plantaricin NC8 alpha & MDKFEKISTSNLEKISGGDLTTKLWSSWGYYLGKKARWNLKHPYVQF & $100 \%$ \\
PlantaricinNC8 beta & MNNLNKFSTLGKSSLSQIEGGSVPTSVYTLGIKILWSAYKHRKTIEKSFNKGFYH & $100 \%$ \\
\hline
\end{tabular}

Table 5. BAGEL4 webserver's prediction of plantaricins and their amino acid sequences produced by Lactobacillus plantarum Mut-7

\begin{tabular}{llc}
\hline $\begin{array}{c}\text { Type of } \\
\text { bacteriocins }\end{array}$ & \multicolumn{1}{c}{ Amino acid sequence } & Match score \\
\hline Plantaricin K & MKIKLTVLNEFEELTADAEKNISGGRRSRKNGIGYAIGYAFGAVERAVLGGSRDYNK & $100 \%$ \\
Plantaricin J & MTVNKMIKDLDVVDAFAPISNNKLNGVVGGGAWKNFWSSLRKGFYDGEAGRAIRR & $100 \%$ \\
Plantaricin N & MKSLDKIAGLGEMAEKDLTTVEGGKNYSKTWWYKSLTLLGKVAEGTSSAWHGLG & $100 \%$ \\
Plantaricin A & VIIMKIQIKGMKQLSNKEMQKIVGGKSSAYSLQMGATAIKQVKKLFKKWGW & $100 \%$ \\
Plantaricin F & MKKFLVLRDRELNAISGGVFHAYSARGVRNNYKSAVGPADWVISAVRGFIHG & $100 \%$ \\
Plantaricin E & MLQFEKLQYSRLLQKKLAKISGGFNRGGYNFGKSVRHVVDAIGSVAGIRGILKSIR & $98.21 \%$ \\
\hline
\end{tabular}


The results of present study highlight the singularity of strains and their metabolic capacities. Both strains were similar in many ways, but some differences were found exclusively in their carbohydrate metabolism, capsule and cell wall synthesis, DNA metabolism, prophage/phage, and bacteriocins production. L. plantarum Mut-7 originated from gatot (fermented dried cassava) possesses a larger genome size than L. plantarum Dad-13 originated from dadih (fermented buffalo's milk). Mut-7 also possesses unique genes for plant carbohydrates metabolism indicating the adaptation to the plant environment. Therefore, Dad-13 produces more types of bacteriocins than Mut-7, which may affect their antibacterial properties.

Our approach to sequence $L$. plantarum from different origins of natural habitat provides quick insight into their diversity. It is essential to isolate and sequence other lactic bacteria from various origins of indigenous fermented foods to untap their metabolic or probiotics potential. Thus, their beneficial properties can be applied to improve food processing, food safety, and human health.

\section{ACKNOWLEDGMENTS}

This research was funded by the Ministry of Research and Technology/National Agency for Research and Innovation (RISTEK-BRIN) through the Higher Education of Research and Development research scheme (PPUPT) with the contract number 2164/UN1/DITLIT/DITLIT/PT/2021 as well as the Center of Excellence for Research and Application on Integrated Probiotic Industry, Universitas Gadjah Mada, with the contract numbers 1256/E3/PKS.04/KL/2021 and 1078/UN1.P.III/DITLIT/PT/2021.

\section{REFERENCES}

Ahaddin AY, Budiarti S, Mustopa AZ, Darusman HS, Triratna L. 2021 Short communication: Acute toxicity study of plantaricin from Lactobacillus plantarum S34 and its antibacterial activity. Biodiversitas 22: 227-232. DOI: 10.13057/biodiv/d220128.

Albayrak ÇB, Duran M. 2021. Isolation and characterization of aroma producing lactic acid bacteria from artisanal white cheese for multifunctional properties. LWT Food Sci Technol 150: 112053. DOI: 10.1016/j.lwt. 2021.112053.

Arasu MV, Jung MW, Ilavenil S, Jane M, Kim DH, Lee KD, Park HS, Hur TY, Choi GJ, Lim YC, Al-Dhabi NA, Choi KC. 2013. Isolation and characterization of antifungal compound from Lactobacillus plantarum KCC-10 from forage silage with potential beneficial properties. J Appl Microbiol 115 (5): 1172-1185. DOI: 10.1111/jam.12319.

Arasu MV, Al-Dhabi NA, Ilavenil S, Choi KC, Srigopalram S. 2016. In vitro importance of probiotic Lactobacillus plantarum related to medical field. Saudi J Biol Sci 23 (1): S6-S10. DOI: 10.1016/j.sjbs.2015.09.022.

Ashaolu TJ, Reale A. 2020. A holistic review on Euro-Asian lactic acid bacteria fermented cereals and vegetables. Microorganisms 8 (8): 1176. DOI: $10.3390 /$ microorganisms 8081176 .

Austin MB, Noe JP. 2003. The chalcone synthase superfamily of type III polyketide synthases. Nat Pro Rep 20 (1): 79-110. DOI: 10.1039/b100917f.

Ayivi RD, Gyawali R , Krastanov R, Aljaloud, SO, Worku, M, Tahergorabi R, da Silva RC, Ibrahim SA. 2020. Lactic acid bacteria: Food safety and human health applications. Dairy 1 (3) : 202-232. DOI: $10.3390 /$ dairy1030015.
Bankevich A, Nurk S, Antipov D, Gurevich AA, Dvorkin M, Kulikov AS, Lesin VM, Nikolenko SI, Pham S, Prjibelski AD, Pyshkin AV, Sirotkin, AV, Vyahhi N, Tesler G, Alekseyev MA,Pevzner, PA. 2012. SPAdes: A new genome assembly algorithm and its applications to single-cell sequencing. J Comput Biol 19 (5): 455-477. DOI: $10.1089 / \mathrm{cmb} .2012 .0021$.

Barbosa J, Albano H, Silva B, Almeida MH, Nogueira T, Teixeira. P. 2021. Characterization of a Lactiplantibacillus plantarum R23 isolated from arugula by whole-genome sequencing and its bacteriocin production ability. Intl J Environ Res Public Health 18 (11): 5515. DOI: 10.3390/ ijerph18115515.

Behera SS, Ray RC, Zdolec N. 2018. Lactobacillus plantarum with functional properties: An approach to increase safety and shelf-life of fermented foods. Biomed Res Intl 2018: 9361614. DOI: $10.1155 / 2018 / 9361614$.

Bengtsson T, Selegård R, Musa A. et al. 2020. Plantaricin NC8 $\alpha \beta$ exerts potent antimicrobial activity against Staphylococcus spp. and enhances the effects of antibiotics. Sci Rep 10: 3580. DOI: 10.1038/s41598-020-60570-w.

Bermudez-brito M,Plaza-Díaz J, Muñoz-Quezada S, Gómez-Llorente C, Gil A. 2012. Probiotic mechanisms of action. Ann Nutr Metab 61:160-174. DOI: 10.1159/000342079.

Blin K, Shaw S, Kloosterman AM, Charlop-Powers, Z, van Wezel GP, Medema MH, Weber T. 2021. antiSMASH 6.0: Improving cluster detection and comparison capabilities. Nucleic Acids Res 49 (W1): W29-W35. DOI: 10.1093/nar/gkab335.

Butorac K, Banić M, Novak J, Leboš Pavunc A, Uroić K, Durgo K, Oršolić N, Kukolj M, Radović S, Scalabrin S, Žučko J, Starčević A, Šušković J, Kos B. 2020. The functional capacity of plantaricinproducing Lactobacillus plantarum SF9C and S-layer-carrying Lactobacillus brevis SF9B to withstand gastrointestinal transit. Microb Cell Factories 19 (1): 106. DOI: 10.1186/s12934-020-013656.

Chapot-Chartier MP, Kulakauskas S. 2014. Cell wall structure and function in lactic acid bacteria. Microb Cell Factories 13: S9. DOI: 10.1186/1475-2859-13-S1-S9.

Deem MW. 2020. CRISPR recognizes as many phage types as possible without overwhelming the cas machinery. Proceed Natl Acad Sci 117 (14): 7550-7552. DOI: 10.1073/pnas.2002746117.

Fečkaninováa A, Koščováb J, Mudroňováb D, Schusterováb P, Maruščákováb IC. Popelkaa P. 2019. Aquac Res 506: 294-301. DOI: 10.1016/j.aquaculture.2019.03.026.

Fhoula I, Najjari A,Turki Y, Jaballah S, Boudabous A, Ouzar H. 2013. Diversity and antimicrobial properties of lactic acid bacteria isolated from rhizosphere of olive trees and desert truffles of Tunisia. Biomed Res Intl 2013: 405708. DOI: 10.1155/2013/405708.

Fitrianingthias RRDR, Utami T, Yanti R, Widada J, Rahayu ES. 2018. Consumption of indigenous probiotic Lactobacillus plantarum Mut-7 powder and fecal population of Lactobacillus, Bifidobacterium, Clostridium, and short chain fatty acids. Intl J Probiotics Prebiotics 13 (4): 143-150.

Garcia-Vello P, Sharma G, Speciale I, Molinaro A, Im SH, De Castro C. 2020. Structural features and immunological perception of the cell surface glycans of Lactobacillus plantarum: A novel rhamnose-rich polysaccharide and teichoic acids. Carbohydr Polym 233: 115857. DOI: 10.1016/j.carbpol.2020.115857.

Gaspar C, Donders GG, Palmeira-de-Oliveira R, Queiroz JA, Tomaz C, Martinez-de-Oliveira J, Palmeira-de-Oliveira A. 2018. Bacteriocin production of the probiotic Lactobacillus acidophilus KS400. AMB Express 8: 153. DOI: 10.1186/s13568-018-0679-z.

Gupta S, Mohanty U, Majumdar RK. 2021. Isolation and characterization of lactic acid bacteria from traditional fermented fish product shidal of India with reference to their probiotic potential. LWT Food Sci Technol 146: 111641. DOI: 10.1016/j.lwt.2021.111641.

He Y, Wang M, Liu M, Huang L, Liu C, Zhang X, Yi H, Cheng A, Zhu D, Yang Q, Wu Y, Zhao X, Chen S, Jia R, Zhang S, Liu Y, Yu Y, Zhang L. 2018. Cas1 and Cas2 from the Type II-C CRISPR-Cas System of Riemerella anatipestifer are required for spacer acquisition. Front Cell Infect Microbiol 8: 195. DOI: 10.3389/fcimb.2018.00195.

Ikhsani AY, Riftyan E, Safitri RA, Marsono Y, Utami T, Widada J, Rahayu ES. 2020. Safety assessment of indigenous probiotic strain Lactobacillus plantarum Mut-7 using sprague dawley rats as a model. Am J Pharmacol 15: 7-16. 
Kareem RA, Razavi S. 2019. Plantaricin bacteriocins: As safe alternative antimicrobial peptides in food preservation - A review. J Food Saf 40: e12735. DOI: $10.1111 /$ jfs. 12735 .

Kim E, Chang HC, Kim HY. 2020. Complete genome sequence of Lactobacillus plantarum EM, a putative probiotic strain with the cholesterol-lowering effect and antimicrobial activity. Curr Microbiol 77 (8): 1871-1882. DOI: 10.1007/s00284-020-02000-8.

Le B, Yang SH. 2018. Efficacy of Lactobacillus plantarum in prevention of inflammatory bowel disease. Toxicol Rep 5: 314-317. DOI: 10.1016/j.toxrep.2018.02.007.

Li M, Wang Y, Cui H, Li Y, Sun Y, Qiu H. 2020. Characterization of lactic acid bacteria isolated from the gastrointestinal tract of a wild boar as potential probiotics. Front Vet Sci 7: 49. DOI: $10.3389 /$ fvets.2020.00049

Lim HJ, Lee E, Yoon Y, Chua B, Son A. 2016a. Portable lysis apparatus for rapid single-step DNA extraction of Bacillus subtilis. J Appl Microbiol 120 (2): 379-387. DOI: 10.1111/jam.13011.

Lim YP, Go MY, Yew WS. 2016b. Exploiting the biosynthetic potential of Type III polyketide synthases. Molecules 21 (6): 806. DOI 10.3390/molecules21060806.

Lin SH, Liao YC .2013. CISA: Contig Integrator for sequence assembly of bacterial genomes. PLoS One 8 (3): e60843. DOI: 10.1371/journal.pone.0060843.

Linares, DM, Gómez C, Renes E, Fresn JM, Tornadijo ME, Ross RP, Stanton C. 2017. Lactic acid bacteria and bifidobacteria with potential to design natural biofunctional health-promoting dairy foods. Front Microbiol 8: 846. DOI: 10.3389/fmicb.2017.00846.

Luo R, Liu B, Xie Y, Li Z., Huang W, Yuan J, He G, Chen Y, Pan Q, Liu Y, Tang J, Wu G, Zhang H, Shi Y, Liu Y, Yu C, Wang B, Lu Y, Han C, Cheung W, Wang J .2012. SOAPdenovo2: An empirically improved memory-efficient short-read de novo assembler. Giga Sci 1 (1): 18. DOI: $10.1186 / 2047-217 \mathrm{X}-1-18$.

Mathur H, Field D, Upton M, Cotter PD. 2021. Editorial: Bacteriocins and other ribosomally synthesised and post-translationally modified peptides (RiPPs) as alternatives to antibiotics. Front Microbiol 12: 695081. DOI: 10.3389/fmicb.2021.695081.

Medjaoui I, Rahmani B, Talhi M, Mahammi FZ, Moghti FZ, Mehtara N, Gaouar SBS. 2016. Isolation and characterization of lactic acid bacteria from human milk and newborn feces. J Pure Appl Microbiol 10 (4): 2613-2620. DOI: 10.22207/JPAM.10.4.17.

Nuraida L. 2015. A review: Health promoting lactic acid bacteria in traditional Indonesian fermented foods. Food Sci Hum Wellness 4 (2): 47-55. DOI: 10.1016/j.fshw.2015.06.001

Overbeek R, Olson R, Pusch G D, Olsen G J, Davis JJ, Dis T, Edwards R A, Gerdes S, Parrello B, Shukla M, Vonstein V, Wattam AR, Xia F, Stevens R. 2014. The seed and the rapid annotation of microbial genomes using subsystems technology (RAST). Nucleic Acids Res 42: D206-D214. DOI: 10.1093/nar/gkt1226.

Prasirtsak B, Tanasupawatb S, Boonsombatc R, Kodamac K, Thongchulc K. 2013. Characterization of lactic acid producing bacteria from Thai sources. J Appl Pharmaceut Sci 3: 33-38. DOI 10.7324/JAPS.2013.30107.

Rahayu ES, Rusdan IH, Athennia A, Kamil RZ, Pramesi PC, Marsono Y, Utami T, Widada J. 2019. Safety assessment of indigenous probiotic strain Lactobacillus plantarum Dad-13 isolated from dadih using sprague dawley rats as a model. Am J Pharmacol 14: 38-47.

Rahayu ES, Cahyanto MN, Windiarti L, Sutriyanto J, Kandarina T, Utami T. 2016. Effects of consumption of fermented milk containing indigenous probiotic Lactobacillus plantarum Dad-13 on the fecal microbiota of healthy Indonesian volunteers. Intl J Probiotics Prebiotics 11 (2): 91-98.

Rahayu ES, Yogeswara A, Mariyatun, Windiarti L, Utami T, Watanabe K. 2015. Molecular characteristics of indigenous probiotic strains from Indonesia. Intl J Probiotics Prebiotics 11 (2): 109-116.

Rahayu ES. 2003. Lactic acid bacteria in fermented-foods of Indonesia origin. Agritech 23 (2): 8. DOI: 10.22146/agritech.13515.

Ramu R, Shirahatti PS, Devia AT, Prasad A, Kumuda J, Lochana MS, Zameer F, Dhananjaya BL, Nagendra Prasat MN. 2015. Bacteriocins and their applications in food preservation. Crit Rev Food Sci Nutr 6: 18. DOI: 10.1080/10408398.2015.1020918.

Richter C, Chang JT, Fineran PC. 2012. Function and regulation of clustered regularly interspaced short palindromic repeats (CRISPR) / CRISPR associated (Cas) systems. Viruses 4 (10): 2291-2311. DOI: $10.3390 / \mathrm{v} 4102291$

Rodrigo-Torres L, Yépez A, Aznar R, Arahal DR. 2019. Genomic insights into five strains of Lactobacillus plantarum with biotechnological potential isolated from Chicha, a traditional maize-based fermented beverage from northwestern Argentina. Front Microbiol 10: 2232. DOI: $10.3389 /$ fmicb.2019.02232.

Sakandar HA, Hussan R, Kubow S, Sadiq FA, Huang W, Imran M. 2019. Sourdough bread: A contemporary cereal fermented product. J Food Process Preserv 43 (3): e13883. DOI: 10.1111/jfpp.13883.

Sarkono, Faturrahman, Sofyan Y. 2010. Isolation and identification of lactic acid bacteria from abalone (Haliotis asinina) as a potential candidate of probiotic. Nusantara Biosci 2: 38-42. DOI: 10.13057/nusbiosci/n020106

Selegård R, Musa A, Nyström P, Aili D, Bengtsson T, Khalaf H. 2019. Plantaricins markedly enhance the effects of traditional antibiotics against Staphylococcus epidermidis. Future Microbiol 14 (3): 195205. DOI: $10.2217 / \mathrm{fmb}-2018-0285$.

Sentürk M, Ercan F, Yalcin S. 2020. The secondary metabolites produced by Lactobacillus plantarum downregulate BCL-2 and BUFFY genes on breast cancer cell line and model organism Drosophila melanogaster: Molecular docking approach. Cancer Chemother Pharmacol 85: 33-45. DOI: 10.1007/s00280-019-03978-0.

Shiroda M, Manning SD. 2020. Lactobacillus strains vary in their ability to interact with human endometrial stromal cells. PLoS One 15 (9): e0238993. DOI: 10.1371/journal. pone.0238993.

Sica MG, Olivera NL, Brugnoni LI, Marucci PL, Cazorla ACL, Cubitto MC. 2010. Isolation, identification and antimicrobial activity of lactic acid bacteria from the Bahía Blanca Estuary. Revista de Biología Marina y Oceanografía 45 (3): 389-397.

Siezen RJ, Starrenburg MJ, Boekhorst J, Renckens B, Molenaar D, van Hylckama VJE. 2008. Genome-scale genotype-phenotype matching of two Lactococcus lactis isolates from plants identifies mechanisms of adaptation to the plant niche. Appl Environ Microbiol 74 (2): 424436. DOI: 10.1128/AEM.01850-07.

Silva LA, Lopes Neto JHP, Cardarelli HR. 2019. Exopolysaccharides produced by Lactobacillus plantarum: Technological properties, biological activity, and potential application in the food industry. Ann Microbiol 69: 321-328. DOI: 10.1007/s13213-019-01456-9.

Simpson JT, Wong K, Jackman SD, Schein JE, Jones SJ, Birol I. 2009. ABySS: A parallel assembler for short read sequence data. Genome Res 19 (6): 1117-1123. DOI: 10.1101/gr.089532.108.

Sophatha B, Piwat S, Teanpaisan R. 2020. Adhesion, anti-adhesion and aggregation properties relating to surface charges of selected Lactobacillus strains: Study in Caco-2 and H357 cells. Arch Microbiol 202: 1349-1357. DOI: 10.1007/s00203-020-01846-7.

Syaputri Y, Iwahashi H. 2020. Characteristics of heterologous plantaricin from Lactobacillus plantarum and its future in food preservation. Rev Agric Sci 8: 124-137. DOI: 10.7831/ras.8.0_124.

Tamang JP, Watanabe K, Holzapfel WH.2016. Review: Diversity of microorganisms in global fermented foods and beverages. Front Microbiol 7: 377. DOI: 10.3389/fmicb.2016.00377.

Tarrah A, Pakroo S, Corich V, Giacomini A. 2020. Whole-genome sequence and comparative genome analysis of Lactobacillus paracasei DTA93, a promising probiotic lactic acid bacterium. Arch Microbiol 202 (7): 1997-2003. DOI: 10.1007/s00203-020-01883-2.

Todorov SD, Holzapfel W, Nero LA. 2016. Characterization of a novel bacteriocin produced by Lactobacillus plantarum ST8SH and some aspects of its mode of action. Ann Microbiol 66: 949-962 DOI: 10.1007/s13213-015-1180-4.

Trush EA, Poluektova EA,Beniashvilli AG, Shifrin OS, Poluektov YM, Ivashkin VT. 2020. The evolution of human probiotics: Challenges and prospects. Probiotics Antimicro Prot 12: 1291-1299. DOI: 10.1007/s12602-019-09628-4.

van Heel AJ, de Jong A, Song C, Viel JH, Kok J, Kuipers OP. 2018. BAGEL4: A user-friendly web server to thoroughly mine RiPPs and bacteriocins. Nucleic Acids Res 46 (W1): W278-W281. DOI: 10.1093/nar/gky383.

Vinogradov E, Sadovskaya I, Grard T, Chapot-Chartier MP. 2016. Structural studies of the rhamnose-rich cell wall polysaccharide of Lactobacillus casei BL23. Carbohydr Res 435: 156-161. DOI: 10.1016/j.carres.2016.10.002.

Waki T, Mameda R, Nakano T, Yamada S, Terashita M, Ito K, Tenma N, Li, Y, Fujino N, Uno K, Yamashita S, Aoki Y, Denessiouk K, Kawai Y, Sugawara S, Saito K, Yonekura-Sakakibara K, Morita Y, Hoshino A, Takahashi S, Nakayama T. 2020. A conserved strategy of chalcone isomerase-like protein to rectify promiscuous chalcone synthase specificity. Nat Commun 11 (1): 870. DOI: 10.1038/s41467-02014558-9. 
Wang Y, Yuxuan Q, Qing X, Ying Z, Jinrong H, Pinglan L. 2018. Purification and characterization of plantaricin LPL-1, a novel class IIa bacteriocin produced by Lactobacillus plantarum LPL-1 isolated from fermented fish. Front Microbiol 9: 2276. DOI: 10.3389/fmicb.2018.02276.

Westra ER, Dowling AJ, Broniewski JM, van Houte S. 2016. Evolution and ecology of CRISPR. Ann Rev Ecol Sys 47 (1): 307-331. DOI: 10.1146/annurev-ecolsys-121415-032428.

Wen LS, Philip K, Ajam N. 2016. Purification, characterization and mode of action of plantaricin K25 produced by Lactobacillus plantarum. Food Control 60: 430-439. DOI: 10.1016/j.foodcont.2015.08.010.

Xiao Y, Zhao J, Zhang H, Zhai Q, Chen W. 2021. Mining genome traits that determine the different gut colonization potential of Lactobacillus and Bifidobacterium species. Microb Genom 7: 000581. DOI: 10.1099/mgen.0.000581

Yu J, Ahn S, Kim K, Caetano-Anolles K, Lee C, Kang J, Cho K, Yoon SH, Kang DK, Kim H. 2017. Comparative genomic analysis of
Lactobacillus plantarum GB-LP1 isolated from traditional Korean fermented food. J Microbiol Biotechnol 27 (8): 1419-1427. DOI: 10.4014/jmb.1704.04005.

Zhang N, Li C, Niu Z, Kang H, Wang M, Zhanga B, Tian H. 2020. Colonization and immunoregulation of Lactobacillus plantarum BF_15, a novel probiotic strain from the feces of breast-fed infants. Food Funct 11: 3156-3166. DOI: 10.1039/C9FO02745A

Zhao S, Han J, Bie X, Lu Z, Zhang C, Fengxia Lv. 2016. Purification and characterization of plantaricin JLA-9: A novel bacteriocin against Bacillus spp. produced by Lactobacillus plantarum JLA-9 from SuanTsai, a traditional chinese fermented cabbage. J Agric Food Chem 64 (13): 2754-2764. DOI: 10.1021/acs.jafc.5b05717.

Zhu X, Zhao Y, Sun Y, Gu Q. 2014. Purification and characterisation of plantaricin ZJ008, a novel bacteriocin against Staphylococcus spp. from Lactobacillus plantarum ZJ008. Food Chem 165: 216-223. DOI: 10.1016/j.foodchem.2014.05.034. 